\title{
Retranslocation of nutrients and zinc sulphate fertilization of banana plants in central Amazon
}

\author{
A. Moreira', L.A.C. Moraes ${ }^{2}$, J.C.R. Pereira ${ }^{2}$ and C. Castro ${ }^{3}$ \\ ${ }^{1}$ Embrapa Cattle Southeast, Rodovia Washington Luiz, Km 234, C.P. 339, 13560-970, São Carlos, São Paulo State, Brazil; \\ ${ }^{2}$ Embrapa Western Amazon, C.P. 319, 69011-970, Manaus, Amazonas State, Brazil; ${ }^{3}$ Embrapa Soybean, C.P. 231, 86001- \\ 970 Londrina, Paraná State, Brazil. Author for correspondence (e-mail:adonis@cppse.embrapa.br)
}

\begin{abstract}
Banana cultivation is ranked as one of the agricultural activities of greatest economic importance and social significance in Brazil. The area under banana cultivation in Brazil (516,000 ha) is larger than India and Ecuador, leading countires in production, but with rather lower productivity due to lack of adequate crop management, particularly fertilizer application. The objective of this work was to investigate the rate of nutrient retranslocation and the effect of fertilization on the yield and uniformity of banana bunches cultivated in central Amazon region. Two field experiments were conducted in a xanthic Ferralsol (dystrophic Yellow Latosol) - predominant soil of the region, examining: a) the nutrient translocation rate in twelve plants; and b) the efficiency of zinc use, in a completely randomized blocks in split plot design with four rates of $\mathrm{ZnSO}_{4}\left(0,30,60\right.$ and $120 \mathrm{~g} \mathrm{plant}^{-1}$ cycle $\left.{ }^{-1}\right)$ and two application times (in the hole together with the seedling or applied in the fifth month after planting), with four replicates. Under the local edaphoclimatic conditions, the results show that $\mathrm{N}, \mathrm{P}, \mathrm{K}, \mathrm{Mg}$ and $\mathrm{Cu}$ have a high retranslocation rate. The plant yield was influenced by the rates of $\mathrm{ZnSO}_{4}$, with the most efficient application method being in the planting hole. Results indicated that at high concentrations, zinc had mobility in the phloem from the leaves to the fruits. The proposed critical leaf zinc concentration at the start of inflorescence was 12.9 $\mathrm{mg} \mathrm{kg}^{-1}$ for the third leaf.
\end{abstract}

Key words: Critical leaf zinc concentration, foliar nutrients, nutrient mobility, Musa spp.

\section{Introduction}

The dynamics of nutrients in fruit-bearing plants is very important in the various processes, such as ripening, growth, senescence and development of physiological disorders (Johnson et al., 1987; Fergunson et al., 1999). Studies on the transport and distribution of zinc in the plants can help in understanding for improved and efficient translocation of the applied nutrients. Still, these studies have received relatively little attention, although some have shown that deficiency at an early growth stages results in significant productivity losses (Pearson and Rengel, 1994; Martinez et al., 2005).

The mineral composition of the leaves is a consequence of factors that influence the absorption, long-distance transport and translocation of mineral elements (Malavolta et al., 1997; Epstein and Bloom, 2005). Leaf diagnosis can be used both as a way to recommend fertilizer rates and to adjust application timing, mainly in perennials. The remobilization of nutrients is important particularly during the reproductive phase, when seeds, fruits and storage organs are formed. At this stage, the root activity usually declines as a result of the decrease in supply of carbohydrates (sink competition) (Marschner, 1995). In plants, zinc is absorbed by the roots and quickly transported to the aerial part. It is partially mobile within the plant and its transport occurs passively through transpiration flow (Epstein and Bloom, 2005). Nevertheless, the transport mechanisms of sap in the xylem are subject of considerable debate (Longnecker and Robson, 1993).

Zinc deficiency in banana plants stunts their growth and causes their leaves to become lanceolate, narrow and yellowed, with chlorotic striping between the secondary veins and yellow coloration on the underleaf surface, mainly in the primary vein. The symptoms are more evident in the fruits, with reduced length and diameter, as a rule in the top and bottom thirds of the bunches. Besides the reduced size, the fruits have a cigar-shape, with green tips (Moreira et al., 2007), and the distance between hands is reduced, giving the bunches a compact appearance (Brown et al., 1993; Borges et al., 1999).

In places where there is a deficiency of $\mathrm{Zn}$, the amount and physiological timing of correct application of the nutrient may be essential to increase the yield, with a greater number of marketable fruits. The objective of this work was to verify the nutrient remobilization rate and establish a suitable critical zinc level in leaf under the edaphoclimatic conditions of the Central Amazon, and to define the best physiological stage for the application of nutrients in the soil.

\section{Material and methods}

Study site: The experiments were conducted in clayey texture (719 $\mathrm{g} \mathrm{kg}^{-1}$ ) and kaolinthic dystrophic Yellow Latosol (Brazilian classification-Embrapa, 1999) - Xanthic Ferralsol (FAO, 1990), with low natural fertility (Table 1), located at the Embrapa Western Amazon experimental station, at coordinates 38' $\mathrm{S}$ and $59^{\circ} 52^{\prime} \mathrm{W}$, in the municipality of Manaus, Amazonas State, Brazil. The natural vegetation is a tropical rainforest. The region's predominant climate is humid tropical, classified as Afi by the Köppen system, with relatively abundant rainfall throughout the year (mean of 2,250 $\mathrm{mm}$ ). The amount of rainfall in the driest 
months (July to September) is always above $60 \mathrm{~mm}$, and the wettest months are February to April. The average temperature is about $26^{\circ} \mathrm{C}$ (Vieira and Santos, 1987).

\section{Experiments}

The field experiments were established in January on an upland area ('terra firme') of about 0.5 ha which first had been cleared for a rubber plantation in 1978, but this had been abandoned with development into secondary forest.

Experiment (a): The experiment was set up with twelve banana plants (cv FHIA 18), grown from tissue culture, in a non-irrigated regime, with periodic defoliations and pruning to determine the rate of nutrient remobilization. At the start of inflorescence, central part of the leaf blade of the third leaf was removed (Malavolta, 1992 - diagnostic leaf) counted from the apex (phase called $\mathrm{F}_{1}$ ), and symmetrically from this same leaf another part at the time of harvesting the bunches ( $p$ hase called $\mathrm{F}_{2}$ ). After collection, the leaf parts were dried at $\pm 65^{\circ} \mathrm{C}$ until they reached constant weight and then were ground and sieved through $0.40-\mathrm{mm}$ mesh. The total $\mathrm{N}$ was extracted by sulfur digestion and determined by the microKjeldahl method (Nelson and Sommers, 1972), while the P, K, $\mathrm{Ca}, \mathrm{Mg}, \mathrm{S}, \mathrm{Cu}, \mathrm{Fe}, \mathrm{Mn}$ and $\mathrm{Zn}$ were extracted by nitropercloric digestion, with the $\mathrm{P}$ and $\mathrm{S}$ determined by spectrophotometry (blue molybdenum photometry) and turbidimetry methods, respectively (Novozamsky et al., 1983). The other nutrients were analyzed by atomic absorption spectrophotometry according to the method described by Malavolta et al. (1997).

To determine the internal retranslocation rate of the nutrients, we calculated the fraction of nutrient retranslocated (FNR), using the following equation, adapted from Ares et al. (2003).

$\mathrm{FNR}=1-\left(\frac{\frac{\mathrm{NF}_{1}}{\mathrm{Ca} \text { or } \mathrm{B} \text { in } \mathrm{NF}_{1}}}{\frac{\mathrm{NF}_{2}}{\mathrm{Ca} \text { or } \mathrm{B} \text { in } \mathrm{NF}_{2}}}\right)$

where,

$\mathrm{NF}_{1}=$ nutrient obtained in the leaf part at the start of flowering;

$\mathrm{NF}_{2}=$ nutrient obtained in the leaf part at the time of harvesting.

The use of the Ca content $\left(\mathrm{g} \mathrm{kg}^{-1}\right)$ for the macronutrients and $\mathrm{B}$ $\left(\mathrm{mg} \mathrm{kg}^{-1}\right)$ for the micronutrients as a comparison variable was due to the low mobility within the plant (Epstein and Bloom, 2005; Malavolta, 2006).

Experiment (b): An experiment was set up with the Thap Maeo cultivar, employing random complete blocks in a $4 \times 2$ factorial scheme in split-plot design, with four replicates. The plots were treated with four rates of $\mathrm{ZnSO}_{4}\left(0,30,60,120 \mathrm{~g}\right.$ plant $^{-1}$ cycle $^{-1}$ $-20 \%$ of $\mathrm{Zn}$ ), while the subplots were the two application times (in the hole at the time of planting the seedling and in the fifth month after planting). The treatments consisted of the average of the data collected from the five central plants of each replicate.

Fertilization: In both the experiments, the spacing was three meters between rows and two meters between plants (1, 667 plants $\left.\mathrm{ha}^{-1}\right)$. Forty-five days before planting, we fertilized the holes (60 x 60 x $60 \mathrm{~cm}$ ) with five liters of chicken manure and $500 \mathrm{~g}$ of dolomitic limestone [Effective Calcium Carbonate $(\mathrm{ECC})=90 \%$ ]. At the time of planting in the remobilization experiment, $60 \mathrm{~g}$ of $\mathrm{P}_{2} \mathrm{O}_{5}$ (single superphosphate $-20 \%$ of $\mathrm{P}_{2} \mathrm{O}_{5}$ ) and $50 \mathrm{~g}$ of fritted trace elements (FTE BR12 ${ }^{\circledR}-\mathrm{B}, 1.8, \mathrm{Cu}, 0.8, \mathrm{Fe}, 3.0, \mathrm{Mn}, 2.0$,
Table 1. Characteristics and nutrient availability in a xanthic Ferralsol (dystrophic Yellow Latosol) located in the municipality of Manaus, Amazonas State, Brazil

\begin{tabular}{lrrr}
\hline Characteristics $^{(1)}$ & & Depth $(\mathrm{cm})$ \\
\cline { 3 - 4 } & $0-10$ & $10-20$ & $20-40$ \\
\hline $\mathrm{pH} \mathrm{in} \mathrm{CaCl}_{2}$ & 3.43 & 3.50 & 3.65 \\
$\mathrm{P}\left(\mathrm{mg} \mathrm{dm}^{-3}\right)$ & 2.94 & 2.28 & 2.02 \\
$\mathrm{~K}\left(\mathrm{mg} \mathrm{dm}^{-3}\right)$ & 25.60 & 17.67 & 14.33 \\
$\mathrm{Ca}\left(\mathrm{cmol}_{\mathrm{c}} \mathrm{dm}^{-3}\right)$ & 0.19 & 0.11 & 0.10 \\
$\mathrm{Mg}\left(\mathrm{cmol}_{\mathrm{c}} \mathrm{dm}^{-3}\right)$ & 0.19 & 0.15 & 0.15 \\
$\mathrm{H}+\mathrm{Al}\left(\mathrm{cmol}_{\mathrm{c}} \mathrm{dm}^{-3}\right)$ & 8.80 & 10.08 & 8.30 \\
$\mathrm{Al}\left(\mathrm{cmol}_{\mathrm{c} \mathrm{dm}}{ }^{-3}\right)$ & 2.12 & 1.58 & 1.09 \\
$\mathrm{~S}\left(\mathrm{mg} \mathrm{dm}^{-3}\right)$ & 19.52 & 19.55 & 32.03 \\
$\mathrm{SOM}\left(\mathrm{g} \mathrm{kg}^{-1}\right)$ & 42.77 & 31.04 & 23.50 \\
$\mathrm{~B}\left(\mathrm{mg} \mathrm{dm}^{-3}\right)$ & 0.34 & 0.30 & 0.25 \\
$\mathrm{Cu}\left(\mathrm{mg} \mathrm{dm}^{-3}\right)$ & 0.11 & 0.10 & 0.08 \\
$\mathrm{Fe}\left(\mathrm{mg} \mathrm{dm}^{-3}\right)$ & 170.07 & 166.67 & 144.57 \\
$\mathrm{Mn}\left(\mathrm{mg} \mathrm{dm}^{-3}\right)$ & 1.90 & 1.25 & 1.26 \\
$\mathrm{Zn}\left(\mathrm{mg} \mathrm{dm}^{-3}\right)$ & 0.67 & 0.47 & 0.35
\end{tabular}

(1) available $\mathrm{P}, \mathrm{K}, \mathrm{Cu}, \mathrm{Fe}, \mathrm{Mn}$ and $\mathrm{Zn}$ was extracted with Mehlich 1; exchangeable $\mathrm{Ca}, \mathrm{Mg}$, Al was determined after extraction with $\mathrm{KCl}$ $1.0 \mathrm{~mol} \mathrm{~L}^{-1}$; exchangeable $\mathrm{H}+\mathrm{Al}$ was with calcium acetate $0.01 \mathrm{~mol}$ $\mathrm{L}^{-1}$; SOM (soil organic matter) $=\mathrm{C} \times 1.724-$ Walkley Black method (Embrapa, 1997).

Mo, 0.1 and $\mathrm{Zn}, 9.0 \%$ ) was applied together with the seedlings while in the $\mathrm{ZnSO}_{4}$ rate experiment (b), the amount of FTE BR12 ${ }^{\circledR}$ was $10 \mathrm{~g}$, only to supply the plants development requirements. The broadcast fertilization consisted of $256 \mathrm{~g}$ plant $^{-1}$ of urea $(44 \%$ of $\mathrm{N})$ and $1,600 \mathrm{~g} \mathrm{plant}^{-1}$ of potassium chloride $\left(58 \%\right.$ of $\left.\mathrm{K}_{2} \mathrm{O}\right)$, distributed in four applications: in the second, fourth, seventh and tenth month after planting (Moreira et al., 2005). The first three fertilizations were done around the plant in a range of $50 \mathrm{~cm}$, and the last in a semicircle beside the daughter plant.

In the fourth month after planting, mulch containing $100 \mathrm{~g}$ of magnesium sulfate $(9 \% \mathrm{Mg}), 20 \mathrm{~g}$ of copper sulfate $(13 \% \mathrm{Cu}), 20$ $\mathrm{g}$ of iron sulfate $(19 \% \mathrm{Fe}), 10 \mathrm{~g}$ of manganese sulfate $(26 \%$ of $\mathrm{Mn})$ and $30 \mathrm{~g}$ of boric acid (17\% of B), and $30 \mathrm{~g}$ of zinc sulfate $(20 \%$ of $\mathrm{Zn}$ ) was applied (Moreira et al., 2005) in the remobilization experiment.

Just as in the remobilization experiment, the $\mathrm{Zn}$ content was determined in the leaves in phases $F_{1}$ and $F_{2}$. At the time of harvesting the bunches, fruit of hands 2, 6 and 10 were sampled to measure the length, diameter and $\mathrm{Zn}$ content of the fruit. In phase $\mathrm{F}_{1}$, the foliar critical concentration was established according to the methodology described by Cate Junior and Nelson (1971) .

Statistical analyses: The data were subjeted to Analysis of Variance (ANOVA). Comparison of least significant differences between means (Tukey test, $P \leq 0.05$ ), and regression analysis at 5\% significance (Pimentel Gomes and Garcia, 2002) was performed.

\section{Results and discussion}

Based on the chemical analyses and soil critical levels established by Moreira et al. (2005) for cultivating banana plants in Amazonas State, it was inferred that independent of the depth, the concentrations of $\mathrm{P}, \mathrm{K}, \mathrm{Ca}, \mathrm{Mg}, \mathrm{B}, \mathrm{Fe}, \mathrm{Mn}$ and $\mathrm{Zn}$ in the 
soil were within the classes considered very low, while the $\mathrm{Al}$ and exchangeable $\mathrm{H}+\mathrm{Al}$ were very high (Table 1). Lehmann et al. (2001) reported $90 \%$ of soils in the Amazonian area had poor fertility. These characteristics were ideal for the study of nutrient translocation in banana plants and their response to fertilization.

The analysis of variance of the yield per hectare and the leaf content of $\mathrm{Zn}$ in phases $\mathrm{F}_{1}$ and $\mathrm{F}_{2}$ indicate a significant effect of the $\mathrm{ZnSO}_{4}$ rates $(P \leq 0.05)$, time of application and interaction of rates versus timing of application (Table 2 ). The plant productivity was greater with fertilization in the planting hole, even with application of $10 \mathrm{~g}$ of FTE BR $12^{\circledR}$ in all treatments to maintain the minimum level of nutrients required for initial development of the seedlings (Table 3). The interactions indicated that even with the incremental responses following a quadratic equation, the application timing did not show the same behaviour as a function of the $\mathrm{ZnSO}_{4}$ rates. To obtain better estimated yield in the local edaphoclimatic conditions, it would be necessary to apply $100.8 \mathrm{~kg} \mathrm{ha}^{-1}$ in the hole to obtain $48.3 \mathrm{t} \mathrm{ha}^{-1}$ cycle $^{-1}$, while in broadcast method the quantity applied would be $129.2 \mathrm{~kg} \mathrm{ha}^{-1}$, with estimated yield of $47.0 \mathrm{t} \mathrm{ha}^{-1} \mathrm{cycle}^{-1}$.

These results show the superiority of zinc sulfate placed in the planting hole. Besides acting on the formation of the fruits (Borges et al., 1999), with elongation of the cells caused by the synthesis of tryptophane, a precursor of indoleacetic acid (Marschner, 1995), zinc is also important during the initial root formation and vegetative growth stages (Malavolta, 2006). In addition to the nutritional aspects, the application in the hole is less expensive, requiring less fertilizer and fewer crop treatments.

Based on the studies of Moreira et al. (2005), on the concentrations of $\mathrm{Ca}$ and $\mathrm{B}$ (Epstein and Bloom, 2005) and on the rate of increment, we found that the retranslocated fractions of $\mathrm{Ca}, \mathrm{Fe}$ and $\mathrm{Mn}$ have low remobilization to the fruits, with most being retained in the leaves (Table 3 ), while B, $\mathrm{Zn}$ and $\mathrm{S}$ had an intermediate retranslocation rate. Regarding the macronutrients, the high rates found for $\mathrm{Mg}, \mathrm{N}, \mathrm{P}$ and $\mathrm{K}$, which agree with the results obtained by Turner and Barkus (1983) and Ares et al. (2003), and confirm the trend of their mobility within the plants described in the literature.

The time of application and the rates of $\mathrm{Zn}$ significantly influenced the concentration of the element in the leaves, and there was also an interaction between these two variables (Table 2). Despite being significant in the two sampling times, the collection done at the start of flowering with incremental rates of $\mathrm{ZnSO}_{4}$ provided a better response than those obtained at the harvest of the bunches. The highest concentrations of $\mathrm{Zn}$ were obtained in the estimated rates of $111.3 \mathrm{~g} \mathrm{plant}^{-1}$ cycle $^{-1}$ and $120 \mathrm{~g} \mathrm{plant}^{-1}$ cycle $^{-1}$, with application in the hole and in broadcast, respectively (Fig. 1a).

The concentrations of $\mathrm{Zn}$ obtained in the leaves collected together with the bunches exhibited a negative interaction with increasing rates (Fig. 1b). Despite the significant effect of the concentrations at rates of 30,60 and $120 \mathrm{~g} \mathrm{plant}^{-1}$ cycle $^{-1}$ in broadcast method showed similarities, differing only with the control. The efficiency of utilization of zinc, defined by the quantity of the element absorbed to increase yield (Tyney and Webb, 1946; Malavolta, 2006), showed that increasing rates diminished the utilization factor in the two application periods. However, this efficiency
Table 2. Analysis of variance of banana yield and foliar $\mathrm{Zn}$ concentration obtained at the initiation of inflorescence (F1) and at harvest of bunches $(\mathrm{F} 2)^{1}$

\begin{tabular}{|c|c|c|c|c|c|}
\hline \multirow{2}{*}{\multicolumn{2}{|c|}{ Sources of variation }} & \multirow{2}{*}{$\begin{array}{l}\text { Degree of } \\
\text { freedom }\end{array}$} & \multirow[t]{2}{*}{ Yield } & \multicolumn{2}{|c|}{ Foliar Zn concentration } \\
\hline & & & & $\mathrm{F}_{1}$ & $\mathrm{~F}_{2}$ \\
\hline \multicolumn{2}{|l|}{ Blocks } & 3 & - & - & - \\
\hline \multicolumn{2}{|l|}{ Rates - A } & 3 & $13.41 * * *$ & $71.89 * * *$ & $4.74 * *$ \\
\hline \multicolumn{2}{|c|}{ Residue (a) } & 9 & - & - & - \\
\hline \multicolumn{2}{|l|}{ Plots } & 15 & - & - & - \\
\hline \multicolumn{2}{|c|}{ Application time - B } & 1 & $5.18^{*}$ & $3.36^{*}$ & $4.90 * *$ \\
\hline \multicolumn{2}{|l|}{$\mathrm{A} \times \mathrm{B}$} & 3 & $5.66^{* *}$ & $5.60 * *$ & $2.69^{*}$ \\
\hline \multicolumn{2}{|c|}{ Residue (b) } & 12 & - & - & - \\
\hline \multicolumn{2}{|l|}{ Total } & 31 & - & - & - \\
\hline \multicolumn{2}{|l|}{ CV \% (a) } & & 6.52 & 3.26 & 14.07 \\
\hline \multicolumn{2}{|l|}{ CV \% (b) } & & 7.67 & 4.59 & 17.13 \\
\hline \multicolumn{6}{|c|}{$\begin{array}{l}1 *, * * \text { and } * * * \text { : significant at } P=0.1, P=0.05, P=0.01 \text {, respectively. } \mathrm{CV} \\
- \text { coefficient of variation. }\end{array}$} \\
\hline \multicolumn{6}{|c|}{$\begin{array}{l}\text { Table } 3 \text {. Foliar concentration, increment and fraction of retranslocation } \\
\text { of nutrients in banana plants cultivated in Central Amazon, Amazonas } \\
\text { State, Brazil }{ }^{1}\end{array}$} \\
\hline \multirow[t]{2}{*}{ Nutrient } & $\mathrm{F}_{1}$ & $\mathrm{~F}_{2}$ & & $\Delta$ & FNR \\
\hline & & \multicolumn{2}{|l|}{$\mathrm{g} \mathrm{kg}^{-1}$} & \multicolumn{2}{|l|}{$\%$} \\
\hline $\mathrm{N}$ & 26.1 & 21.7 & & -16.9 & -0.73 \\
\hline $\mathrm{P}$ & 1.7 & 1.4 & & -17.6 & -0.72 \\
\hline $\mathrm{K}$ & 27.5 & 22.5 & & -18.2 & -0.74 \\
\hline $\mathrm{Ca}$ & 4.7 & 6.6 & & 40.4 & - \\
\hline $\mathrm{Mg}$ & 2.9 & 2.2 & & -24.1 & -0.83 \\
\hline \multirow[t]{2}{*}{$\mathrm{S}$} & 1.7 & 1.9 & & 11.8 & -0.24 \\
\hline & \multicolumn{3}{|c|}{$\mathrm{mg} \mathrm{kg}^{-1}$} & & \\
\hline B & 19.3 & 17.5 & & -9.3 & - \\
\hline $\mathrm{Cu}$ & 5.5 & 3.4 & & -38.2 & -0.56 \\
\hline $\mathrm{Fe}$ & 52.4 & 92.6 & & 76.7 & 0.45 \\
\hline $\mathrm{Mn}$ & 280.0 & 540.1 & & 92.9 & 0.50 \\
\hline $\mathrm{Zn}$ & 13.0 & 14.0 & & 7.7 & 0.05 \\
\hline
\end{tabular}

${ }^{1} \mathrm{~F}_{1}-$ Foliar concentration at the initiation of inflorescence. $\mathrm{F}_{2}-$ foliar concentration at harvest of bunches. $\Delta$ - increment of foliar level. FNR - fraction of nutrient retranslocated.

was highest when the fertilizer was applied in the planting hole (Fig. 1c and 4), indicating that even though there was nutrient mobilization from "mother" to "daughter" plant (Lahav, 1995), it is more advantageous to accumulate the nutrient in the tissue (redistribution) than to fertilize the plant at the start of its metabolism to form bunches (Malavolta, et al., 1997).

In plants grown in $\mathrm{Zn}$ deficient conditions, the fruits are stronger sinks, creating a greater demand for the nutrient. These observations corroborate with the results obtained by Longnecker and Robson (1993) and Martinez et al. (2005), that tissues undergoing growth, in the case of fruits (Webb and Loneragan, 1990), are preferred zinc sinks as compared to mature tissues. The authors reported that in plants grown with the highest $\mathrm{Zn}$ rates, the sink effects of the growing tissues are not strong. Although our preliminary results showed a low retranslocation rate of zinc to the growing organs (Table 3 ), the higher concentration observed in the leaves collected at phase $\mathrm{F}_{2}$ in the control, along with the greater $\mathrm{Zn}$ content in the central fruit of hand 2, the next-to-last hand produced (Fig. 4), also indicates the mobility pattern of zinc in banana plants. 


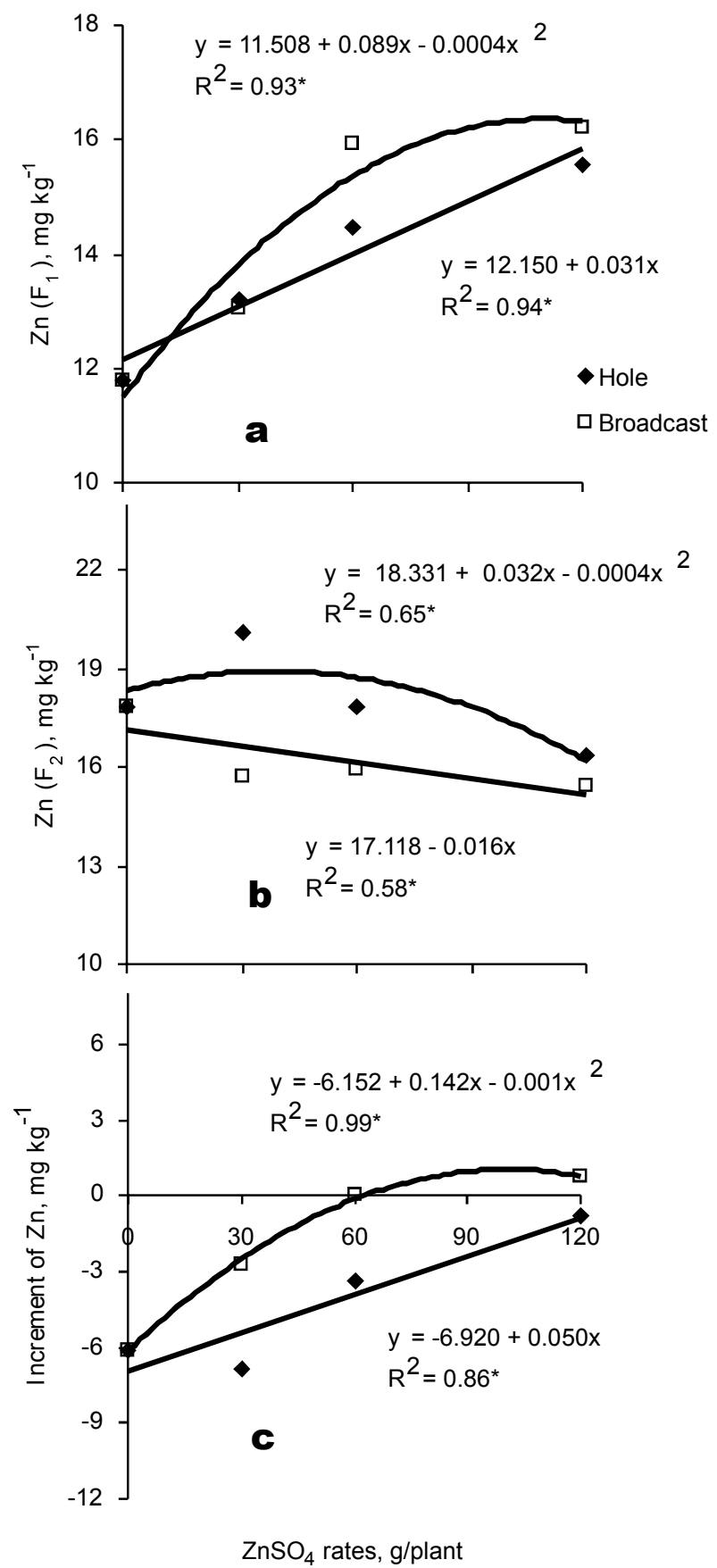

Fig. 1. Effect of zinc sulfate on foliar $\mathrm{Zn}$ concentration at intiation of the inflorescence $\left(\mathrm{F}_{1}\right)$, harvest of bunches $\left(\mathrm{F}_{2}\right)$ and increment of nutrient in leaf, as a function of sampling times. * Significant at $P=0.05$.

Regarding the application time, it was observed that except for the rate of $60 \mathrm{~g} \mathrm{plant}^{-1}$, the quantities of $\mathrm{Zn}$ in the tissue were similar. Moreira et al. (2005) suggested 16 to $22 \mathrm{mg} \mathrm{kg}^{-1}$ as the critical range for zinc in banana plants grown in Amazonas State. Using this index as a reference, it was found that only the treatments with $120 \mathrm{~g} \mathrm{plant}^{-1}$ of $\mathrm{ZnSO}_{4}$ at the two application times were within this sufficiency range (Fig. 1).

The relationship between relative yield and $\mathrm{Zn}$ leaf concentration (Fig. 3) indicates that the critical level obtained for banana plants, using the procedure proposed by Cate Junior and Nelson (1971), was $12.9 \mathrm{mg} \mathrm{kg}^{-1}$, a concentration below the 16 to $19 \mathrm{mg} \mathrm{kg}^{-1}$ and 15 to $23 \mathrm{mg} \mathrm{kg}^{-1}$ suggested by Moreira et al. (2005) and Borges et al. (2006), respectively, for the same cultivar. However, taking the high yield obtained, above $35 \mathrm{t} \mathrm{ha}^{-1}$ cycle $^{-1}$ as a base (Fig.1),

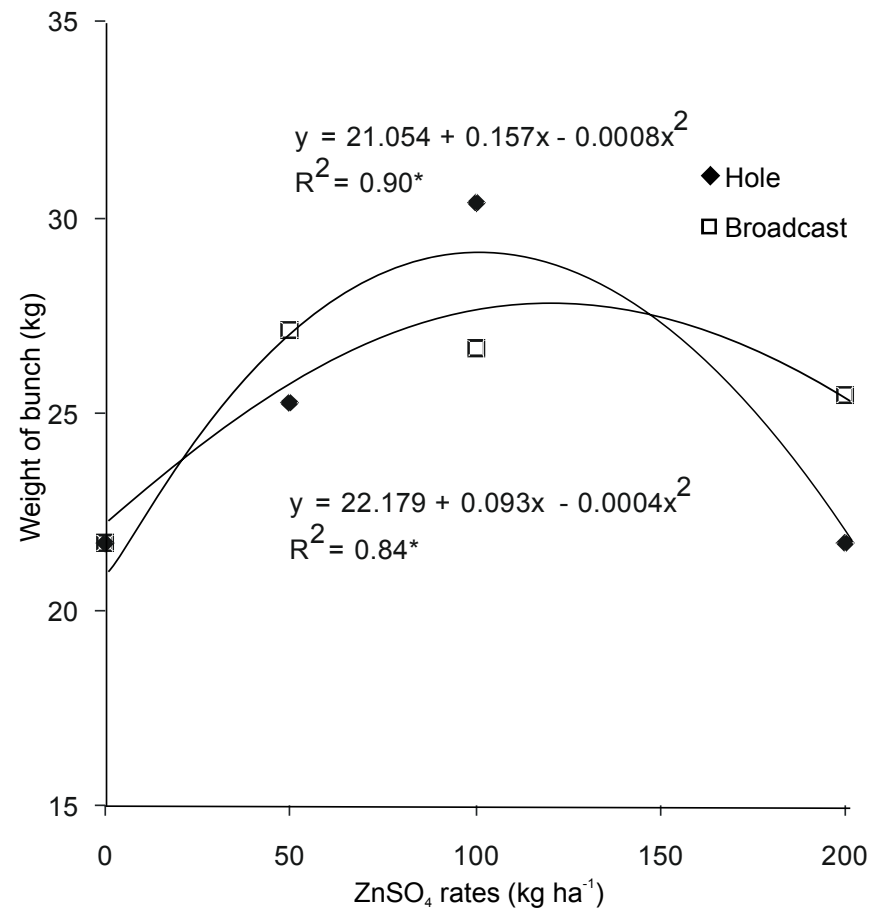

Fig. 2. The effect of zinc sulphate rates on the banana yield cultivated in xanthic Ferralsol (dystrophic Yellow Latosol), as a function of time and fertilization. * Significant at $P=0.05$.

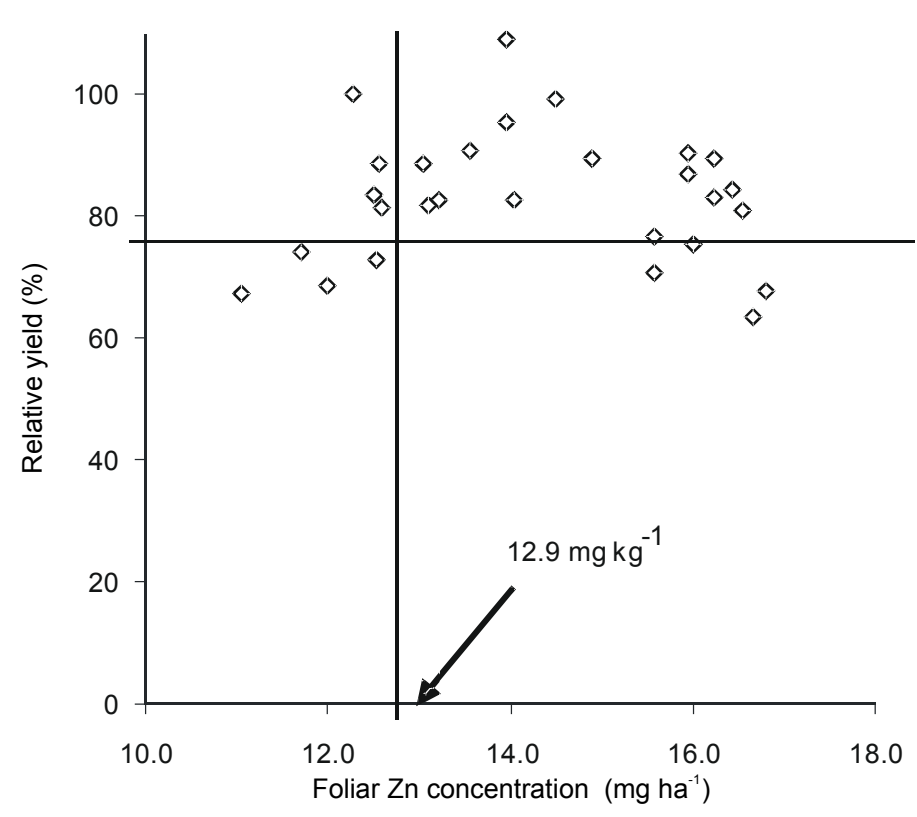

Fig. 3. Relationship between relative yield and foliar zinc concentration in diagnostic leaf at intiation of the inflorescence $\left(F_{1}\right)$ in banana plants cultivated in a xanthic Ferralsol (dystrophic Yellow Latosol), as a function of zinc sulfate rates and time of fertilization.

only the control remained below this sufficiency level. Besides dilution effect (Marschner, 1995) caused by the high productivity, different climatic conditions at the time of collection of the leaves for foliar diagnosis could also have influenced the result.

According to the hands produced (2,6 and 10), there was a significant decrease in fruit length and diameter (Fig. 4). Extrapolating the classification of the 'Prata' subgroup (ABANORTE, 1998) to the Thap Maeo subgroup, the bananas of hand 10 were on average within the second-grade banana 

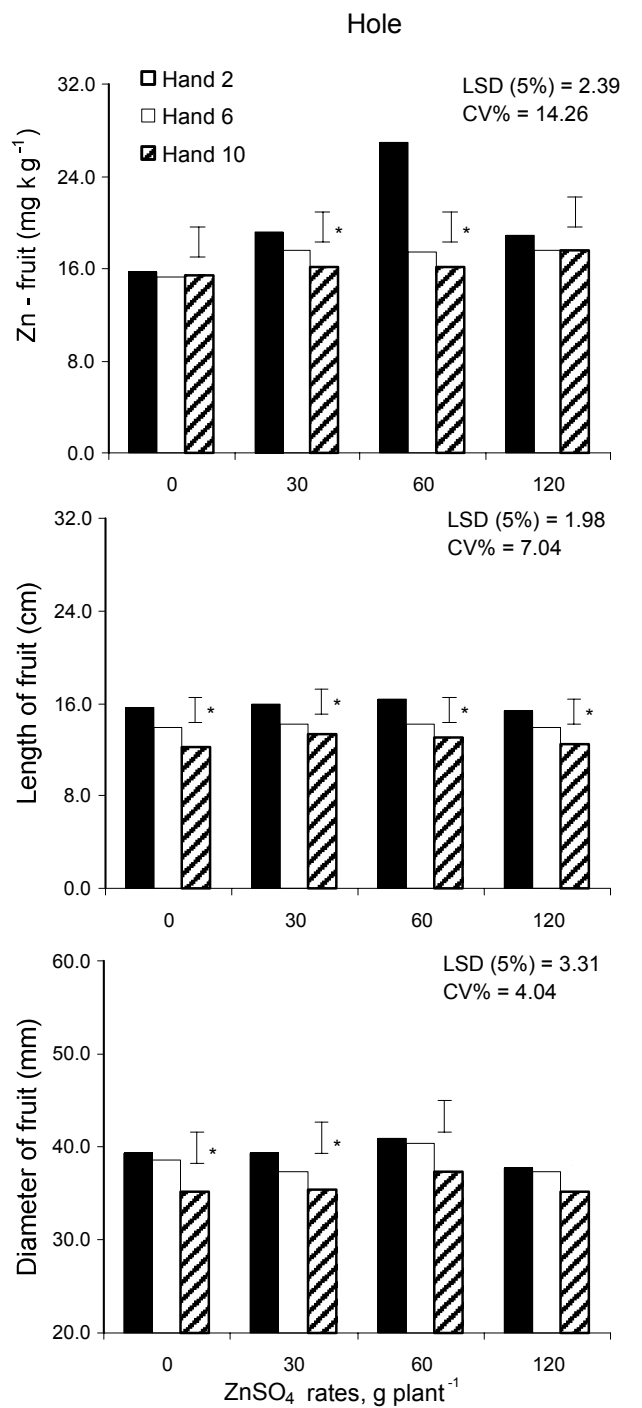

Broadcast

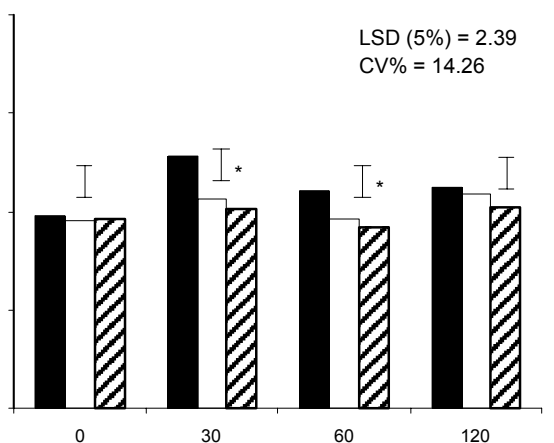

$\operatorname{LSD}(5 \%)=1.98$

$\mathrm{CV} \%=7.04$

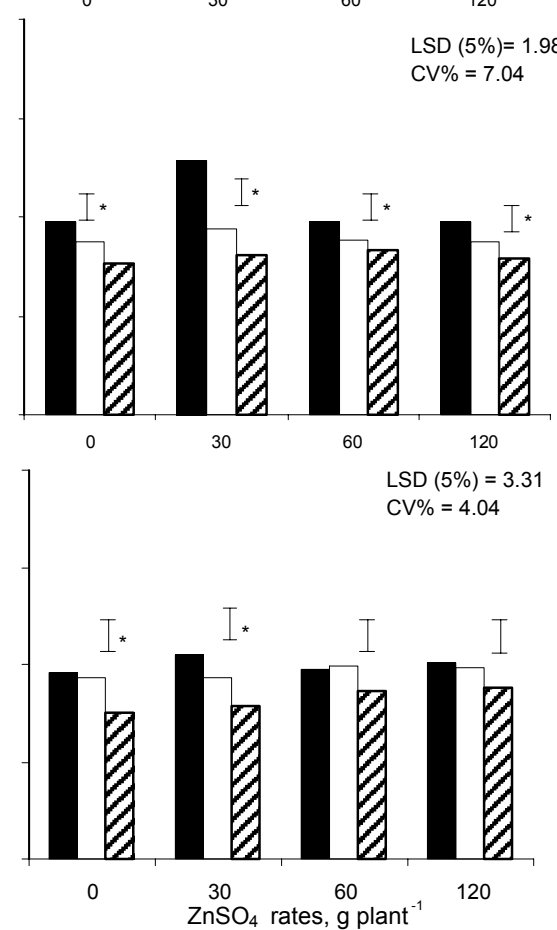

Fig. 4. $\mathrm{Zn}$ concentration $\left(\mathrm{mg} \mathrm{kg}^{-1}\right)$, length $(\mathrm{cm})$ and diameter $(\mathrm{mm})$ of fruits as influenced by $\mathrm{ZnSO}_{4}$ rates $\left(0,30,60\right.$ and 120 g plant $\left.^{-1}\right)$. *Significant at $P=0.05$.

classification (length $<14 \mathrm{~cm}$ ), while for those from hands 2 and 6 the classification was first-grade and export-grade (length $>$ $14 \mathrm{~cm}$ ). Based on the diameter, the bananas from all three hands analyzed were within the first- and export-grade classification (diameter $>32 \mathrm{~mm}$ ). The application times had similar results, with the length of the fruits presenting significant statistical differences for the four rates of $\mathrm{ZnSO}_{4}$, while for the diameter the differences were only significant for the rates of 0 and $30 \mathrm{~g} \mathrm{plant}^{-1}$ cycle $^{-1}$ (Fig. 4). This shows that the zinc was retranslocated from the older fruits, located in the tenth and sixth hands, to the second hand (the penultimate hand produced). Regarding the rates, they did not influence the diameter and length of the fruits.

These results reveal that banana plant yield can be boosted through administration of $\mathrm{ZnSO}_{4}$, in increasing rates according to the market and sales pattern (weight, unit or bunch), For example, unlike in the Center-South region of Brazil, where the fruit is sold in boxes of detached groups, in the North nearly all are sold by bunch.

The results show that in banana plants, the retranslocated fractions of $\mathrm{Ca}, \mathrm{Fe}$ and $\mathrm{Mn}$ have low remobilization, while $\mathrm{B}, \mathrm{Zn}$ and $\mathrm{S}$ were intermediate. The high rates were found for $\mathrm{Mg}, \mathrm{N}, \mathrm{P}$ and $\mathrm{K}$. The productivity of the banana plant is influenced by the rates of zinc sulfate. In the first cycle, the application of $\mathrm{ZnSO}_{4}$ in the planting hole is more efficient than broadcast application after planting in mulch. In the local edaphoclimatic conditions, the proposed critical foliar concentration of zinc in the banana leaf is $12.9 \mathrm{mg} \mathrm{kg}^{-1}$. In banana plant, zinc mobility in the phloem from the leaves to the fruits and from the older to the younger fruits is indicated.

\section{Acknowledgments}

The authors wish to thank Embrapa Western Amazon (CPAA, Manaus) and Produquímica Company for the logistic support (field experiment and laboratory facilities) and donation of the fertilizers, respectively.

\section{References}

Abanorte, 1998. Proposta de padronização para banana Prata Anã do Norte de Minas Gerais. Janaúba, Associação Central dos Produtores de Norte de Minas Gerais, 24 pp.

Ares, A, N. Falcão, K. Yuyama, R.S. Yost and C.R. Clement, 2003 Response to fertilization and nutrient deficiency diagnostic in peach palm in Central Amazonia. Nutr. Cycl. Agroecosyst., 66: 221-232.

Borges, A.L., A.M.G. Oliveira and S.L. Oliveira, 1999. Solos, nutrição e adubação. In: A cultura da banana; aspectos técnicos socioeconômicos e agroindustriais. Ed. E J Alves. Embrapa-SPI, Brasília. pp. 197-260. 
Borges, A.L., S.O. Silva, R.C. Caldas and C.A.S. Ledo, 2006. Teores foliares de nutrientes em genótipos de bananeira. Rev. Bras. Frut. 28: 314-318.

Brown, P.H., I. Cakmak and Q. Zhang, 1993. Form and function of zinc plants. In: Zinc in soil and plants. Ed. A.D. Robson. Kluwer Academic Publishers, Dordrecht. pp. 93-106.

Cate, Junior R.B. and L.A. Nelson, 1971. A simple statistical procedure for partitioning soil test correlation data into two classes. Soil Sci. Soc. Am. Proc., 35: 658-660.

Embrapa, 1997. Manual de métodos de análise de solo. CNPS/Embrapa. Rio de Janeiro. 212 pp.

Embrapa, 1999. Sistema brasileiro de classificação de solos. SPI/ Embrapa. Brasília. 412 pp.

Epstein, E. and A.J. Bloom, 2005. Mineral nutrition of plants; principles and perspectives. Sinauer, Sunderland, $400 \mathrm{pp}$.

FAO, 1990. Soil Map of the World, Revised Legend. FAO, Rome, Italy.

Lahav, E. 1995. Banana nutrition. In: Banana and Plantains. Ed. S Gowen. Chapman and Hall, London. pp. 259-297.

Lehmann, J., M.S. Cravo, J.L.V. Macêdo, A. Moreira and G. Schroth, 2001. Phosphorus management for crops in central Amazonian upland soils. Plant Soil., 237: 309-319.

Longnecker, N.E. and A.D. Robson, 1993. Distribution and transport of zinc in plants. In: Zinc in soil and plants. Ed. A.D. Robson, Kluwer Academic Publishers, Dordrecht. pp.79-92.

Malavolta, E. 2006. Manual de nutrição mineral de plantas. Agronômica Ceres, Piracicaba. 631 pp.

Malavolta, E., G.C. Vitti and S.A. Oliveira, 1997. Avaliação do estado nutricional das plantas: princípios e aplicações. Potafós, Piracicaba., $319 \mathrm{pp}$.

Marschner, H. 1995. Mineral nutrition of higher plants. Academic Press, London. 889 pp.
Martinez, H.E.P., A.V. Zabini, I.A.L. Franco and R.F. Novais, 2005. Translocação e compartimentação de Zn em função de rates aplicadas em feijoeiro e cafeeiro via radicular. Cien Rural., 35: 491-497.

Moreira, A., M.R. Arruda, J.C.R. Pereira, L. Gasparotto and M.C.N. Pereira, 2005. Recomendação de adubação e calagem para bananeira no Estado do Amazonas (1 aproximação). Embrapa Amazônia Ocidental, Manaus. 22pp

Moreira, A., L. Gasparotto, M.R. Arruda, 2007. Papel do zinco na produtividade da bananeira Embrapa Amazônia Ocidental, Manaus. $4 \mathrm{pp}$.

Nelson, D.W. and L.E. Sommers, 1972. Determination of total nitrogen in plant material. Agron. J., 65: 109-112.

Novozamsky, I., V.J.G.Houba, R. van Eck and W. van Vark, 1983. A novel digestion technique for multi-element plant analysis. Commun. Soil. Sci. Plant Anal., 14: 239-248.

Pearson, J.N. and Z. Rengel, 1994. Distribution and remobililization of $\mathrm{Zn}$ and Mn during grain development in wheat. J. Exp. Bot., 45: 829-1835.

Pimentel, Gomes F. and C.H. Garcia, 2002. Estatística aplicada a experimentos agronômicos e florestais. FEALQ, Piracicaba. 309 pp.

Turner, D.W. and B. Barkus, 1983. The uptake and distribution of mineral nutrients in the banana in response to supply of $\mathrm{K}, \mathrm{Mg}$ and Mn. Fertil. Res., 4: 89-99.

Tyney, E.H. and J.W. Weeb, 1946. The relation of corn yields to nutrient balance as revealed by leaf analysis. J. Am. Soc. Agr., 38: 173-185.

Vieira, L.S. and P.C.T.C. Santos, 1987. Amazônia; seus solos e outros recursos naturais. Agronômica Ceres, Piracicaba. 416 pp.

Webb, W.J. and J.F. Loneragan, 1990. Zinc translocation to wheat roots and its implications for a phosphorus/zinc interaction in wheat plants. J. Plant Nut., 13: 1499-1515. 